\title{
Reading Literacy and Learning Strategies in First Language Learning: A Multilevel Approach
}

\author{
Mohammad Madallh Alhabahba ${ }^{1}$, Reem Ibrahim Rabadi ${ }^{2} \&$ Omer Hassan Ali Mahfoodh ${ }^{3}$ \\ ${ }^{1}$ English Language Department, Middle East University, Amman, Jordan \\ ${ }^{2}$ Department of Languages, School of Applied Humanities and Languages, German Jordanian University \\ Amman, Jordan \\ ${ }^{3}$ School of languages, Literacies and Translation, Universiti Sains Malaysia, Malaysia \\ Correspondence: Mohammad Madallh Alhabahba, English Language Department, Middle East University, \\ Amman, Jordan. E-mail: mohammadhabahba@gmail.com
}

Received: January 11, $2017 \quad$ Accepted: April 10, $2017 \quad$ Online Published: July 16, 2017
doi:10.5539/ijel.v7n4p236

\begin{abstract}
This study documents an investigation of multilevel data from the 2009 Program for International Student Assessment to examine the reading literacy of 5,944 15-year-old students in Jordanian schools. A multilevel model was employed to examine the factors linked to students' reading literacy from both students' and schools' levels. At students' level, the study revealed that metacognition, elaboration, memorization, structuring, and scaffolding strategies were significant predictors of students' reading literacy. At schools' level, the study showed that school type, extracurricular activities, and teachers' behaviour were significant predictors of students' reading literacy. Practical implications and recommendations to research community at local and international levels are provided in this study.
\end{abstract}

Keywords: learning strategies, metacognition strategy, reading literacy, students

\section{Introduction}

Reading skills are conceived as operative mechanisms to acquire, organize, and apply knowledge in an "information society" (Artelt, Schiefele, \& Schneider, 2001). This requires students to master reading skills in order to become productive and successful individuals in societies. The ability to read is an important skill in different subjects at school-level and information pursued by students' curiosity mechanism to learn is widely offered in liner and none-liner texts (Artelt et al., 2001). In other words, reading literacy is viewed as the most important skill that school students must develop (Netten, Luyten, Droop, \& Verhoeven, 2014). Therefore, policymakers as well as researchers have developed increasing interests in large-scale assessments such as the Program for International Student Assessment (PISA), which is an internationally standardised assessment that examines students' abilities in several subjects such as reading literacy, mathematics achievement, and science literacy (Areepattamannil, 2014). One of the aims that PISA focuses on is to measure the students' ability to use existing skills and knowledge to succeed in life challenges, rather than focusing only on the magnitude to which they have learned a particular contextual curriculum (Organisation for Economic Co-operation and Development, 2010). Several studies on students' achievements (Chiu, Chow, \& Mcbride-Chang, 2007; Sun, Bradley, \& Akers, 2012; Thorpe, 2006) have contributed to better understanding of reading literacy. These studies have emphasized understating the differences and similarities among students in respect to thinking and knowledge in reading literacy. In addition, these studies have stressed that international comparative tests provide varieties of texts and items in order to measure reading literacy based on modern tests standards. Consequently, many countries have started to recall for reform in education at all levels [66] by means of participating in international assessments such as PISA, which allows them to monitor students' progress at schools in comparison to other countries around the world.

Although several countries have started to participate in PISA and a number of studies have used PISA results to investigate issues related to the aspects dealt with in PISA assessment, little is known about how various school-level factors and their links to student-level factors might influence students' reading literacy. Thus, this study explores the factors that influence students' reading literacy in Jordan. In addition, it reveals the 
relationship between their reading literacy and their learning strategies as metacognition strategies, elaboration strategies, scaffolding strategies, and rote memorization.

\section{Reading Literacy and Learning Strategies}

Several studies have been conducted to understand the relationship between readers and reading comprehension (Barnes, Ahmed, Barth, \& Francis, 2015; Becker, McElvany, \& Kortenbruck, 2010; Moore \& Wade, 1998). They relied heavily on studies conducted with printed texts. There have been a noticeable reference to both theories of cognitive representation and aspects memory development (McMaster et al., 2015). With reference to the complex connections between reading literacy and learning strategies according to (León \& Escudero, 2015), individual predictors of discourse comprehension has been an area of interests to researchers. The results indicated, for example, the significant role of motivational variables, prior and metacognitive knowledge on developing reading skills (Huang, 2013; Maier \& Richter, 2014). At the same time, there has been recent interest in the influence of student-level and school-level characteristics on students reading achievement (Chiu et al., 2007; Lee, Zuze, \& Ross, 2005; Marks, 2005; Stoet \& Geary, 2013; Suggate, 2009) using large-scale assessments such as these found in PISA (Organisation for Economic Co-operation and Development, 2010) and many other large-scale assessments such as TIMSS. Although PISA assesses the knowledge and life skills, individual differences in reading literacy and reading skills have gained crucial importance nowadays.

Reading literacy is defined, according to PISA, as "an individual's capacity to understanding, use and reflect on and engage with written texts, in order to achieve one's goals, to develop one's knowledge and potential and to participate in society" (OECD, 2010, p. 14). It refers to the ability to comprehend texts and to apply acquired information from written texts valued by individuals or/and expected by societies in today's information age (Mullis, Kennedy, Martin, \& Sainsbury, 2006). Considering this definition, the mechanism that operates in comprehending a text depends on students' perceptions of effective instructions. Educators agree that there is a connection between comprehension and critical thinking (Note 1) because being a critical thinker; a learner might be able to minimize or avoid rote memorization. However, this ideal setting was given silent attention in many third world countries, including the Arab countries, in which teachers simply apply rote-learning technique (Alhabahba, Pandian, \& Mahfoodh, 2016). Rather than depending on merely decoding information, students should activate prior knowledge to comprehend new information (Swan, 2003). Thus, students are able to play an active role in the acquisition of information. Putting oneself in such role demands an active state of texts structure to understand how learning strategies function in comprehending pieces of information (Swan, 2003).

In the state of failure to construct situational or propositional representations of texts information, readers fail to generate relevant information in their working memory (Artelt et al., 2001). As the process of reading texts includes reserving related information in the working memory causing readers to regulate the coherence of acquired information. For readers to self-regulate this inner state, they need to employ active topic and discourse knowledge to regulate both old and new selected acquired information (Artelt et al., 2001; Kintsch, 1998).

Considering that learning strategies are mental processes, their role in helping readers is to achieve cognitive process (e.g., acquire, select, store) during reading act (Flavell, 1979). These mental processes are controllable, potentially conscious, and effort-consuming (Flavell, Miller, \& Miller, 1985). Previous research revealed that students who tended to use learning strategies show higher achievement (Taboada, Tonks, Wigfield, \& Guthrie, 2009; Vermunt \& Vermetten, 2004). For example, students' metacognitive skills in prevocational education were found to have a positive effect on reading comprehension (Steensel, Oostdam, Gelderen, \& Schooten, 2014). Likewise, gifted students were found to be skilled in using self-regulating learning strategies (Neber \& Schommer-Aikins, 2002).

As for the case of surface cognitive strategies (Note 2), memorization skills might help students to construct basic skills and enhance memory performance (Haggis, 2003; Rao \& Sachs, 1999). However, studies performed on memorization skills have suggested possible delayed retrieval of information causing more challenges, especially in complicated tasks. Therefore, studies that have been carried out in different cultures warned against increasing practises of rote learning in classrooms (Morrison \& Joan, 2002), especially in Arab countries according to McDevitt (2004). Transferring new learnt knowledge into new learning situations through maximizing elaboration strategies might be an alternative to traditional rote learning.

Elaboration strategies are cognitive processes that connect prior knowledge and target information (Hamilton, 2012), for instance, the use of personal examples in new learning situations. It is considered that these strategies establish links with prior knowledge in order to facilitate access and information recall (Glogger, Schwonke, Holzäpfel, Nückles, \& Renkl, 2012). When problem-solving tasks are used, elaboration strategies will help students to attain deep processing as well as flexible transformation to succeed in these tasks. Regarding this, 
Wolters, Pintrich, \& Karabenick (2005) concluded that elaboration strategies mirror a profounder approach to learning, by approaching to briefing learning martial in hand and, thus, integrate into one's own thoughts and ideas. It is apparent that there is an agreement among researchers over placing an emphasis on teaching elaboration strategies in classrooms to make flexible transformation to students' new knowledge. Berger \& Karabenick (2011) have concluded that students who perceive themselves more capable in mathematics and regarded mathematics more valuable use elaboration and metacognitive strategies more often. However, teachers' practices can hinder this transformation when they choose to ignore strong prompts or do not explicitly train students on how elaboration strategies can be applied to prior knowledge and link to new acquired information. In such a scenario, transformation is often unlikely to occur (Garner, 1990).

A possible solution to overcome such a learning difficulty is the usage of metacognition strategies to enhance students' transferring prior knowledge. Metacognition is knowledge and regulation of one's cognition (Flavell, 1979). Several studies revealed that students using metacognition strategies as learning strategies can enhance their performance (Mevarech \& Kramarski, 2003; Teong, 2003) and reading comprehension (Kolić-Vehovec \& Bajšanski, 2006). In addition, some other studies indicated that guided students on using metacognitive strategies to solve mathematical problem tasks showed better performance of experimental group compared to the control group (Mevarech \& Kramarski, 2003).

Scaffolding strategies, on the other hand, refer to the joint interaction between teachers and students in problem solving activities (Wood, Bruner, \& Ross, 1976). Asking questions or modelling for different subjects are examples of scaffolding strategies in which learning to complete a problem-solving task would not occur without teachers' support (Stone, 1998). According to Stone (1988), students and teachers must be active participants in an interpersonal process with the aim of completing tasks successfully. With regard to metacognition strategies, studies indicated that students respond more effectively and significantly to "talk" as a tool for reasoning and talk-based activities helped in scaffolding the development of reasoning and scientific information acquisition (Mercer, Dawes, Wegerif, \& Sams, 2004). However, teachers play a key role, in facilitating scaffolding in classrooms. According to Mertzman (2008), teachers' planned approaches to literacy instruction conflicted with interruption patterns, "when and how to support and guide students" (p. 183).

In addition to the above mentioned strategies, it is worth discussing school context variables such as teachers' behaviour and their effect on students' achievement.

\section{School Context Variables}

Teachers' behaviour was a concern to many researchers in different contexts as Stormont, Reinke, Newcomer, Marchese, \& Lewis (2014) and Stuhlman \& Pianta (2002) because it affects students' performance (Denton \& Hasbrouck, 2009; Stormont et al., 2014). Numerous studies implied that students' behaviour is related to school achievement, behaviour problems among students are associated with low-academic achievement and low school connectedness (Konishi, Hymel, Zumbo, \& Li, 2010; Pas, Cash, O’Brennan, Debnam, \& Bradshaw, 2015). To create a positive school climate and positive classroom-learning environment, teachers can encourage a learning setting through management strategies when they implement efficient social intervention as separating students or involving parents (Clunies-Ross, Little, \& Kienhuis, 2008; Epstein, Atkins, Cullinan, Kutash, \& Weaver, 2008; Stormont et al., 2014). This possibility can also be promoted by integrating extracurricular activities where students can sense their connectedness to school (i.e., school is a social influencer in developing young learners life) that can also decrease problem behaviours (Brown \& Evans, 2002). If a learning setting considers promoting extracurricular activities in developing youth learning, students may sense their attachment to a prosocial context and, thus, behave prosocially (Brown \& Evans, 2002). Through this connection, students' misbehaviour is likely to be decreased and their academic achievement is promoted (Brown \& Evans, 2002).

However, research on school variables, such as teachers' behaviour and their effect on students' achievements in Arab educational contexts is less documented. As a result, our major goal is to reflect on the issue of students' misbehaviour in Arab schools and the reason behind the increase in students' assault to peers and teachers in this context. Media headlines have repeatedly reported cases of students' misbehavers (Mathher, 2015). These problems range from classrooms problems to violence outside classrooms $(97.7 \%$ of respondents reported violence in schools) (Ohsako, 1997). Some more findings regarding these issues have been reported in some Arab countries. For example, a recent report by media indicated that Teachers Syndicate in Jordan has claimed that 56 severe assault cases to teachers as well as to peers were recorded in 2014-2015 (Jordanian Teachers Syndicate, 2015). With the former findings in mind, it seems that concerns regarding the function of schools in Arab countries have been the focus of discussion and debate. All these issues related to school variables may reveal that social intervention to train teachers to improve students' social and behavioural outcomes is an urgent 
need.

The purpose of this study is to use Multilevel Modelling (MLM) to investigate the factors that influence school students' reading literacy in Jordan. To our knowledge, as far as first language reading literacy in the Arab context is concerned, there are a few studies investigating this linguistic aspect. Another aspect of the contributions of this study lies in the use of MLM which was not been used adequately in previous studies. For this study, MLM is the most appropriate analysis technique due the nature of the data structure in PISA assessment. That is, students are tested in class at schools. Some other statistical techniques were first considered such as Analysis of Covariance (ANCOVA) and regression analysis. It was found that these techniques were inappropriate for the analysis of the data of this study because of the independence assumption (Raudenbush \& Bryk, 2002). Furthermore, results obtained from such estimations, such as ANOVA and regression, could result into misleading information, findings and practical recommendations to those who hold responsibilities to develop educational policies.

\section{Method}

This study used the 2009 Jordan sample as the main focus of PISA in 2009 was "assessment of reading literacy, which is an essential skill for people to acquire knowledge in an increasingly global, information-based world" (Wu, 2005, p. 1). The 2009 version of PISA is the fourth cycle of this popular assessment method (Brozo et al., 2014).

The prediction of reading literacy of the study was examined through the employment of MLM. Specifically, the relationship between various variables related to learning strategies at student-level and teacher behaviour, school type, and extracurricular activities at school-level was explored.

\subsection{Data Source}

The obtained data for the present study were drawn from the 2009 Jordan sample contains 6, 018 10th grade students $(\mathrm{M}$ grade $=9.91, \mathrm{SD}$ grade $=0.32)$ nested in 210 schools. While the sampling method used in PISA studies was randomly groups of 15 -year-old students.

\subsection{Variables}

The dependent variable was reading literacy, which was measured by reading literacy test scores in the 2009 PISA. Traditional tests scores were not employed instead plausible values were used in PISA scores as students worked on one test booklet so the length of the test would be shorter, therefore, students completed different tests which required the use of plausible values instead on traditional ones. Wu (2005) provided some more details on the use of plausible values in PISA assessment. In PISA, there are five plausible values to present Jordanian students reading literacy (PV1READ to PV5READ).

Based on previous discussion, it was concluded that variables related to learning strategies at student-level were of importance to explore their effects on reading literacy. These variables were metacognition-summarising, metacognition-understanding and remembering, use of elaboration strategies, use of memorisation strategies, use of structuring and scaffolding strategies, and use of control strategies. Furthermore, at the school-level, the variables were school type, extracurricular activities, and students' behaviour was included in the final analysis.

\section{Statistical Analysis}

A two-level model was developed to examine the factors that influence reading literacy scores at student-level and school-level. The data structure, as indicated earlier, occurs in many educational settings. That is, students are nested within classes within schools within states and so on (Hox, 2010). Therefore, MLM was carried out as analysis technique. In addition, HLM7 (Hierarchical Linear Models) was used to handle the plausible values in PISA assessment. It creates the outcome variable reading the plausible values in earlier stages of the analysis. Sampling weights were also provided for both schools and students by PISA in order to give corrections for any imperfections in the Jordan sample. For example, this technique was used to avoid bias and any other possible departures between the reference population and the sample. In the current analysis, variables at the school-level and student-level were centred on their means to limit the likelihood of multicollinearity problem. This technique, grand mean centring, helped in interpreting the results in a more meaningful way. Missing data were not an issue because the sample was very large and the tests were not much different without the cases with missing data and, therefore, listwise deletion method was applied for handling missing data. The trimming technique was employed to determine whether variables used had significant relative effect on reading literacy as dependent variable when other variables are held constant. The aim of the trimming technique was used to reveal the least complex model that best predict reading literacy (Micceri, 2007). 


\subsection{Steps in Modelling the Effect of Student-and School-Levels Variables}

Three steps were implemented in order to achieve the goals of the study. First, a null model was created without any predictors from student-level or school-level variables. This step is similar to ANOVA random effect model in which information that includes the variances within and between schools for reading literacy is provided (Ma \& Klinger, 2000). The second step was performed to develop a student-level model without the addition of the school-level predictors. This procedure helped in understanding the effects of student-level variables on reading literacy achievement. In the third step, the school-level variables were included. This full model was developed to recognise the factors at the school-level affecting students' reading literacy.

\section{Results}

The study used the 2009 Jordan sample to achieve its objectives employing MLM approach.

Table 1 below displays the descriptive statistics for the independent variables at both student-level and school-level.

Table 1. Descriptive statistics for independent variables

\begin{tabular}{llll}
\hline Variable & $\mathrm{N}$ & $M$ & $S D$ \\
\hline Student characteristics & & & \\
Metacognition-summarising & 5944 & -0.55 & 1.00 \\
Elaboration strategies & 5944 & 0.64 & 0.99 \\
Memorisation strategies & 5944 & 0.64 & 1.05 \\
Structuring and scaffolding strategies & 5944 & 0.11 & 1.22 \\
\hline School characteristics & & & \\
School type & 209 & 0.14 & 0.36 \\
Extracurricular activities & 209 & 0.66 & 1.06 \\
Teacher behaviour & 209 & -0.54 & 1.10 \\
\hline
\end{tabular}

Whereas Table 2 and Table 3 depict the results obtained from the null model that was examined based on Equation 1:

Level one Model:

$$
\text { Reading literacy }_{i j}=\beta_{0 j}+r_{i j}
$$

Level two Model:

$$
\beta_{0 \mathrm{j}}=\gamma_{00}+\mathrm{u}_{0 \mathrm{j}}
$$

As noted in Equation 1, the dependent variable is reading literacy represented by literacy score ij, literacy score for student $\mathrm{i}$ in school $\mathrm{j}$, the average literacy score for the school $\mathrm{j}$ is represented by $\beta_{0 j}$, this intercept varies across school-level. $r_{i j}$ is the error term denoting an effect linked with student $\mathrm{i}$ in school $\mathrm{j}$. The grand of reading literacy is denoted by the intercept $\gamma_{00}$ and the error term is represented by $\mathrm{u}_{0 j}$ which represents an effect linked with school $\mathrm{j}$.

Table 2 indicates the average of reading literacy score of Jordan sample, 402.95 points. Using the international PISA scale $(M=500, S D=100)$, the Jordanian students scored lower than the international average students did.

Table 2. Fixed effects in null model

\begin{tabular}{llllll}
\hline Fixed & Coefficient & $\mathrm{SE}$ & $T$-ratio & $P$-value & Reliability estimate \\
\hline Intercept (reading literacy) $\gamma_{00}$ & 402.95 & 3.79 & 106.19 & $<0.001$ & 0.94 \\
\hline
\end{tabular}

At the school-level, the variance component was 2,788.76 and the variance component at student level was $5,121.37$ as demonstrated in Table 3. The result suggested a large variance of reading literacy across Jordanian schools $(\chi 2(208)=2,788.76, p<0.001)$. Intra-class correlation of $0.3,525$ indicated that $35.25 \%$ of the total variance in reading literacy was attributable to the school effect. 
Table 3. Random effects in null model

\begin{tabular}{lllll}
\hline & Variance & $d f$ & $\chi^{2}$ & $p$-value \\
\hline Between-school variability (intercept) & 2788.76 & 208 & 3293.96 & $<0.001$ \\
Within-school variability & 5121.37 & & & \\
\hline
\end{tabular}

The final full model of this research is illustrated in the following Equation 2.

Level 1 Model:

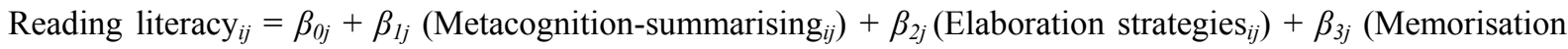
strategies $\left._{i j}\right)+\beta_{4 j}\left(\right.$ Structuring and scaffolding strategies $\left._{i j}\right)+r_{i j}$

Level 2 Model:

$\beta_{0 j}=\gamma_{00}+\gamma_{01}\left(\right.$ School type $\left._{j}\right)+\gamma_{02}\left(\right.$ Extracurricular activities $\left._{j}\right)+\gamma_{03}\left(\right.$ Teacher Behaviour $\left._{j}\right)+u_{0 j}$,

$\beta_{1 j}=\gamma_{10}$

$\beta_{4 j}=\gamma_{40}$

Where $\beta_{l j}$ is the coefficient of metacognition-summarising, measuring the relationship between metacognition-summarising and student reading literacy score in school $j$, for example. $\gamma_{01}$ is the coefficient of school type, measuring the relationship between school type and school reading literacy score in level 2, for example.

The results obtained from HLM software program are displayed in Table 4 and 5. Reliability estimate (i.e., 0.90) result suggested that it was appropriate to consider the least square estimate of the coefficient $\left(\beta_{0 j}\right)$ to distinguish students' reading literacy achievement among schools.

When MLM is fit at both school and student levels, the effects of student-level factors can be understood more meaningfully (Ma, Ma, \& Bradley, 2008). As Table 4 blow presents metacognition-summarising, elaboration, memorisation, and structuring and scaffolding strategies influenced students' reading literacy score. The coefficient $(\gamma)$ of each independent variable was the relative effect which was adjusted for other variables in the model. For every unit increase in metacognition-summarising, for example, students' reading literacy increased 16.03 points when holding other variables constant. A similar pattern can be also found in other variables at the student-level. In comparison to the null model, the final model in the current analysis explained about $50 \%$ of the variance between schools $\left(R^{2}=0.50\right)$ and about $11.83 \%$ of the variance within schools $\left(R^{2}=0.1183\right)$.

Table 4. Fixed effects in full model

\begin{tabular}{lllll}
\hline Fixed Effect & Coefficient & SE & t-ratio & p-value \\
\hline Intercept (reading literacy), $\gamma 00$ & 404.40 & 2.88 & 140.269 & $<0.001$ \\
Student characteristics & & & & \\
Metacognition, $\gamma 10$ & 16.03 & 1.03 & 15.44 & $<0.001$ \\
Elaboration, $\gamma 20$ & 10.17 & 1.38 & 7.33 & $<0.001$ \\
Memorisation, $\gamma 30$ & 8.65 & 1.43 & 6.02 & $<0.001$ \\
Structuring, $\gamma 40$ & 3.66 & 0.89 & 4.11 & $<0.001$ \\
\hline School characteristics & & & & \\
School type (public $=0$, private $=1$ ), $\gamma 02$ & 17.11 & 7.09 & 2.41 & 0.017 \\
Extracurricular activities, $\gamma 03$ & 12.05 & 2.92 & 4.11 & $<0.001$ \\
Teacher Behaviour, $\gamma 04$ & 5.48 & 2.64 & 2.07 & 0.039 \\
\hline
\end{tabular}

At the school-level as Table 5 exhibits, school type, extracurricular activities, and teacher behaviour were found to be effective predictors of the average reading literacy score at each school. In this full model, the intercept of school-level variables can be interpreted as follows: for every unit increase in extracurricular activities, students reading literacy increased 12.05 points when other variables held constant $\left(\gamma_{03}=12.05\right)$. 
Table 5. Random effects in full model

\begin{tabular}{lllll}
\hline Random Effect & Variance & d.f. & $\chi^{2}$ & $p$-value \\
\hline Between-school variability (intercept) & 1391.98 & 204 & $2,010.73$ & $<0.001$ \\
Within-school variability & 4515.13 & & & \\
\hline
\end{tabular}

All slopes (coefficients) in students' level variables were positive. This suggests two important points. First, the positive coefficient of school type in school-level variables suggest that on average private schools scored about 17 points higher than those of public schools when controlling other variables in the model. Second, all other variables contributed positively to students' reading literacy.

\section{Discussion}

The main purpose of this study is to examine and describe antecedents of reading literacy from a large-scale assessment study, PISA. Statistically significant results were found in the Jordan sample. Further, Jordanian students' score in reading literacy was significantly lower than the international scale. At student-level variables, on average students with higher metacognition strategies score was higher than those who reported less use of metacognition strategies use in relation to reading. The other variables at student-level demonstrated a similar pattern. The results are in line with research concerning the positive effects of metacognition on students' reading (Alhabahba, Pandian, \& Mahfoodh, 2016; Lee \& Schmitt, 2014; Maier \& Richter, 2014; Mevarech \& Kramarski, 2003), elaboration strategies (Glogger et al., 2012; Hamilton, 2012), memorization strategies (Wolters et al., 2005), and scaffolding strategies (Mertzman, 2008).

We assume, at the students' level, that students' needs and usage of the reading strategies in reading, especially metacognition, is taxing but needs further investigation. These pedagogical characteristics seem to reveal that targeted and systemic reading strategies should be deliberately integrated into the reading curricula with full guidance, as Kirschner, Sweller, \& Clark (2006) recommended. This may help in delivering reading activities to the students for effective learning. Within schools, this facilitation is more effectively functional in private schools than public schools. At school-level, private schools scored higher in reading literacy. This finding is consistent with other studies conducted on the effects of school type on students' achievements (Jehangir, Glas, \& van den Berg, 2015). Not a surprising result to the context of Jordan (this is also applicable to many other countries in the region). Lack of professional development, effective teaching practices, motivation towards learning, and funding to support learning and teaching environment at public schools are amongst possible reasons for this finding. It is necessary to point out the differences between public and private schools funding. According to Corten \& Dronkers (2006), private schools depend on tuition fees and parental fundraising of which both function, at least in Jordan, as a proxy for delivering quality service, learning and teaching. It seems the environment of teaching and learning in privte sector does benefit from funding resources. This features in providing professional development to teachers and educational resources which in turn may have an impact on students' outcome.

A recent report by USAID (2008) concluded that the general teaching and learning paradigm is still "teacher-centered approach" p. 25. This finding was concluded after a "Discovery school" project (Note 3) was injected in public schools, which aimed at integrating information and communication technology in classrooms. With reference to teaching practices, we have also observed the effect of school type on reading literacy for private schools but not for public schools. It might be the effect contrasting instructional strategies where teachers in private schools use and, thus, these instructional strategies might be transferred to promote effective classroom learning. For example, in private schools teachers extend maximum efforts to care for every student learning and, therefore, professional development and educational resources available to them magnitude that aim (Alhabahba \& Mahfoodh, 2016), from business viewpoint at least.

\section{Limitations}

This study as it is correlational in nature, therefore, assuming causality between reading strategies and reading literacy should not be raised. Some suggestions are recommended for future studies. First, future research in the field of first language reading should consider longitudinal methodology to probe further investigations into the dynamics underneath relations at present unknown (e.g., parents' involvement in students learning). Second, this study can be expanded to wider population as considering gender (Note 4) and socioeconomic variables among teachers and students to extend understanding reading literacy. 


\section{References}

Alhabahba, M. M., \& Mahfoodh, O. H. A. (2016). The Use of the Internet for English Language Teachers' Professional Development in Arab Countries. Australian Journal of Teacher Education, 41(4), 1-19. https://doi.org/10.14221/ajte.2016v41n4.1

Alhabahba, M. M., Pandian, A., \& Mahfoodh, O. H. A. (2016). The effect of integrated instructions on reading comprehension, motivation, and cognitive variables. Issues in Educational Research, 26(3), 387-406.

Alhabahba, M. M., Pandian, A., \& Mahfoodh, O. H. A. (2016). English language education in Jordan: Some recent trends and challenges. Cogent Education, 3(1), 1-14. https://doi.org/10.1080/2331186X.2016.1156809

Areepattamannil, S. (2014). International Note: What factors are associated with reading, mathematics, and science literacy of Indian adolescents? A multilevel examination. Journal of Adolescence, 37(4), $367-372$. https://doi.org/10.1016/j.adolescence.2014.02.007

Artelt, C., Schiefele, U., \& Schneider, W. (2001). Predictors of reading literacy. European Journal of Psychology of Education, 16(3), 363-383. https://doi.org/10.1007/BF03173188

Barnes, M. A., Ahmed, Y., Barth, A., \& Francis, D. J. (2015). The Relation of Knowledge-Text Integration Processes and Reading Comprehension in 7th-to 12th-Grade Students. Scientific Studies of Reading, 19(4), 1-20. https://doi.org/10.1080/10888438.2015.1022650

Becker, M., McElvany, N., \& Kortenbruck, M. (2010). Intrinsic and extrinsic reading motivation as predictors of reading literacy: A longitudinal study. Journal of Educational Psychology, 102(4), 773. https://doi.org/10.1037/a0020084

Berger, J. L., \& Karabenick, S. A. (2011). Motivation and students' use of learning strategies: Evidence of unidirectional effects in mathematics classrooms. Learning and Instruction, 21(3), 416-428. https://doi.org/10.1016/j.learninstruc.2010.06.002

Brown, R., \& Evans, W. P. (2002). Extracurricular activity and ethnicity creating greater school connection among diverse student populations. Urban Education, 37(1), 41-58. https://doi.org/10.1177/0042085902371004

Brozo, W. G., Sulkunen, S., Shiel, G., Garbe, C., Pandian, A., \& Valtin, R. (2014). Reading, Gender, and Engagement. Journal of Adolescent \& Adult Literacy, 57(7), 584-593. https://doi.org/10.1002/jaal.291

Chiu, M. M., Chow, B. W. Y., \& Mcbride-Chang, C. (2007). Universals and specifics in learning strategies: Explaining adolescent mathematics, science, and reading achievement across 34 countries. Learning and Individual Differences, 17(4), 344-365. https://doi.org/10.1016/j.lindif.2007.03.007

Clunies-Ross, P., Little, E., \& Kienhuis, M. (2008). Self - reported and actual use of proactive and reactive classroom management strategies and their relationship with teacher stress and student behaviour. Educational Psychology, 28(6), 693-710. https://doi.org/10.1080/01443410802206700

Corten, R., \& Dronkers, J. (2006). School achievement of pupils from the lower strata in public, private government-dependent and private government-independent schools: A cross-national test of the Coleman-Hoffer thesis 1. Educational Research and Evaluation, 12(02), 179-208. https://doi.org/10.1080/13803610600587032

Denton, C. A., \& Hasbrouck, J. (2009). A description of instructional coaching and its relationship to consultation. Journal of Educational and Psychological Consultation, 19(2), 150-175. https://doi.org/10.1080/10474410802463296

Epstein, M., Atkins, M., Cullinan, D., Kutash, K., \& Weaver, K. (2008). Reducing behavior problems in the elementary school classroom: National Center for Education Evaluation and Regional Assistance.

Flavell, J. H. (1979). Metacognition and cognitive monitoring: A new area of cognitive-developmental inquiry. American Psychologist, 34(10), 906-911. https://doi.org/10.1037/0003-066X.34.10.906

Flavell, J. H., Miller, P. H., \& Miller, S. A. (1985). Cognitive Development. NJ: Prentice-Hall Englewood Cliffs.

Garner, R. (1990). When children and adults do not use learning strategies: Toward a theory of settings. Review of Educational Research, 60(4), 517-529. https://doi.org/10.3102/00346543060004517

Garrison, D. R., Anderson, T., \& Archer, W. (2001). Critical thinking, cognitive presence, and computer conferencing in distance education. American Journal of Distance Education, 15(1), 7-23. 
https://doi.org/10.1080/08923640109527071

Glogger, I., Schwonke, R., Holzäpfel, L., Nückles, M., \& Renkl, A. (2012). Learning strategies assessed by journal writing: Prediction of learning outcomes by quantity, quality, and combinations of learning strategies. Journal of Educational Psychology, 104(2), 452. https://doi.org/10.1037/a0026683

Haggis, T. (2003). Constructing images of ourselves? A critical investigation into "approaches to learning" research in higher education. British Educational Research Journal, 29(1), 89-104. https://doi.org/10.1080/0141192032000057401

Hamilton, R. (2012). Elaboration Effects on Learning. In N. M. Seel (Ed.), Encyclopedia of the Sciences of Learning (pp. 1103-1105). New York: Springer.

Hox, J. (2010). Multilevel analysis: Techniques and applications. New York, London: Routledge.

Huang, S. (2013). Factors Affecting Middle School Students' Reading Motivation in Taiwan. Reading Psychology, 34(2), 148-181. https://doi.org/10.1080/02702711.2011.618799

Jehangir, K., Glas, C. A., \& van den Berg, S. (2015). Exploring the relation between socio-economic status and reading achievement in PISA 2009 through an intercepts-and-slopes-as-outcomes paradigm. International Journal of Educational Research, 71, 1-15. https://doi.org/10.1016/j.ijer.2015.02.002

Jordanian Teachers Syndicate. (2015). Shoking results inTawjihi examination results. Retrieved from http://jts.org.jo/index.php/en

Kintsch, W. (1998). Comprehension: A paradigm for cognition. Cambridge: Cambridge university press.

Kirschner, P. A., Sweller, J., \& Clark, R. E. (2006). Why minimal guidance during instruction does not work: An analysis of the failure of constructivist, discovery, problem-based, experiential, and inquiry-based teaching. Educational Psychologist, 41(2), 75-86. https://doi.org/10.1207/s15326985ep4102_1

Kolić-Vehovec, S., \& Bajšanski, I. (2006). Metacognitive strategies and reading comprehension in elementary-school students. European Journal of Psychology of Education, 21(4), 439-451. https://doi.org/10.1007/BF03173513

Konishi, C., Hymel, S., Zumbo, B. D., \& Li, Z. (2010). Do school bullying and student-teacher relationships matter for academic achievement? A multilevel analysis. Canadian Journal of School Psychology, 25(1), 19-39. https://doi.org/10.1177/0829573509357550

Lee, \& Schmitt, M. C. (2014). Teacher Language Scaffolds the Development of Independent Strategic Reading Activities and Metacognitive Awareness in Emergent Readers. Reading Psychology, 35(1), 32-57. https://doi.org/10.1080/02702711.2012.674477

Lee, V. E., Zuze, T. L., \& Ross, K. N. (2005). School effectiveness in 14 sub-Saharan African countries: Links with 6 th Graders' reading achievement. Studies in Educational Evaluation, 31(2), 207-246. https://doi.org/10.1016/j.stueduc.2005.05.011

León, J. A., \& Escudero, I. (2015). Understanding Causality in Science Discourse for Middle and High School Students. Summary task as a Strategy for Improving Comprehension. In K. L. Santi \& D. K. Reed (Eds.), Improving Reading Comprehension of Middle and High School Students (pp. 75-98). New York: Springer. https://doi.org/10.1007/978-3-319-14735-2_4

Ma, X., \& Klinger, D. A. (2000). Hierarchical linear modelling of student and school effects on academic achievement. Canadian Journal of Education, 25(1), 41-55. https://doi.org/10.2307/1585867

Ma, X., Ma, L., \& Bradley, K. D. (2008). Using multilevel modeling to investigate school effects. In A. A. O'Connell \& D. B. McCoach (Eds.), Multilevel Modeling of Educational Data (pp. 59-110). Charlotte, NC: Information Age.

Maier, J., \& Richter, T. (2014). Fostering multiple text comprehension: How metacognitive strategies and motivation moderate the text-belief consistency effect. Metacognition and Learning, 9(1), 51-74. https://doi.org/10.1007/s11409-013-9111-x

Marks, G. N. (2005). Accounting for immigrant non-immigrant differences in reading and mathematics in twenty countries. Ethnic and Racial Studies, 28(5), 925-946. https://doi.org/10.1080/01419870500158943

Mathher, A. (2015). Assault phenomenon on teachers is aggravated. Retrieved from http://www.alghad.com/

McDevitt, B. (2004). Negotiating the syllabus: a win-win situation? ELT Journal, 58(1), 3-9. https://doi.org/10.1093/elt/58.1.3 
McMaster, K. L., van den Broek, P., Espin, C. A., Pinto, V., Janda, B., Lam, E., ... van Boekel, M. (2015). Developing a reading comprehension intervention: Translating cognitive theory to educational practice. Contemporary Educational Psychology, 40, 28-40. https://doi.org/10.1016/j.cedpsych.2014.04.001

Mercer, N., Dawes, L., Wegerif, R., \& Sams, C. (2004). Reasoning as a scientist: ways of helping children to use language to learn science. British Educational Research Journal, 30(3), 359-377. https://doi.org/10.1080/01411920410001689689

Mertzman, T. (2008). Individualising scaffolding: teachers' literacy interruptions of ethnic minority students and students from low socioeconomic backgrounds. Journal of Research in Reading, 31(2), 183-202. https://doi.org/10.1111/j.1467-9817.2007.00356.x

Mevarech, Z. R., \& Kramarski, B. (2003). The effects of metacognitive training versus worked-out examples on students' mathematical reasoning. British Journal of Educational Psychology, 73(4), 449-471. https://doi.org/10.1348/000709903322591181

Micceri, T. (2007). The Use of Multilevel Modeling to Estimate Which Measures Are Most Influential in Determining an Institution's Placement in Carnegie's New Doctoral/Research University Classification Schema. Online Submission.

Moore, M., \& Wade, B. (1998). Reading and Comprehension: a longitudinal study of ex-Reading Recovery students. Educational Studies, 24(2), 195-203. https://doi.org/10.1080/0305569980240205

Morrison, K., \& Joan, T. F. H. (2002). Testing to destruction: a problem in a small state. Assessment in Education: Principles, Policy \& Practice, 9(3), 289-317. https://doi.org/10.1080/0969594022000027654a

Mullis, I. V., Kennedy, A. M., Martin, M. O., \& Sainsbury, M. (2006). Assessment Framework and Specifications Chestnut Hill, MA: Boston College.

Neber, H., \& Schommer-Aikins, M. (2002). Self-regulated science learning with highly gifted students: The role of cognitive, motivational, epistemological, and environmental variables. High Ability Studies, 13(1), 59-74. https://doi.org/10.1080/13598130220132316

Netten, A., Luyten, H., Droop, M., \& Verhoeven, L. (2014). Role of linguistic and sociocultural diversity in reading literacy achievement: a multilevel approach. Journal of Research in Reading, 1-20.

Ohsako, T. (1997). Violence at School: Global Issues and Interventions. Studies in Comparative Education: ERIC.

Organisation for Economic Co-operation and Development. (2010). Assessment Framework: Key competencies in reading, mathematics and science.

Pas, E. T., Cash, A. H., O’Brennan, L., Debnam, K. J., \& Bradshaw, C. P. (2015). Profiles of classroom behavior in high schools: Associations with teacher behavior management strategies and classroom composition. Journal of School Psychology, 53(2), 137-148. https://doi.org/10.1016/j.jsp.2014.12.005

Rao, N., \& Sachs, J. (1999). Confirmatory factor analysis of the Chinese version of the motivated strategies for learning questionnaire. Educational and Psychological Measurement, 59(6), 1016-1029. https://doi.org/10.1177/00131649921970206

Steensel, R., Oostdam, R., Gelderen, A., \& Schooten, E. (2014). The role of word decoding, vocabulary knowledge and metacognitive knowledge in monolingual and bilingual low-achieving adolescents' reading comprehension. Journal of Research in Reading, Early view, 1-18.

Stoet, G., \& Geary, D. C. (2013). Sex differences in mathematics and reading achievement are inversely related: Within-and across-nation assessment of 10 years of PISA data. PloS one, 8(3), 1-10. https://doi.org/10.1371/journal.pone.0057988

Stone, C. A. (1998). What is missing in the metaphor of scaffolding? In E. A. Forman, N. M. Minick \& C. A. Stone (Eds.), Contexts for Learning. Sociocultural Dynamics in Children's Development (Vol. 2, pp. 169-183). New York: Oxford University Press.

Stormont, M., Reinke, W. M., Newcomer, L., Marchese, D., \& Lewis, C. (2014). Coaching Teachers' Use of Social Behavior Interventions to Improve Children's Outcomes A Review of the Literature. Journal of Positive Behavior Interventions, 17(2), 69-82. https://doi.org/10.1177/1098300714550657

Stuhlman, M. W., \& Pianta, R. C. (2002). Teachers' narratives about their relationships with children: Associations with behavior in classrooms. School Psychology Review, 31(2), 148-163. 
Suggate, S. P. (2009). School entry age and reading achievement in the 2006 Programme for International Student Assessment (PISA). International Journal of Educational Research, 48(3), 151-161. https://doi.org/10.1016/j.ijer.2009.05.001

Sun, L., Bradley, K. D., \& Akers, K. (2012). A multilevel modelling approach to investigating factors impacting science achievement for secondary school students: PISA Hong Kong sample. International Journal of Science Education, 34(14), 2107-2125. https://doi.org/10.1080/09500693.2012.708063

Swan, E. A. (2003). Concept-oriented reading instruction: Engaging classrooms, lifelong learners. New York: The Guilford Press.

Taboada, A., Tonks, S. M., Wigfield, A., \& Guthrie, J. T. (2009). Effects of motivational and cognitive variables on reading comprehension. Reading and Writing, 22(1), 85-106. https://doi.org/10.1007/s11145-008-9133-y

Teong, S. (2003). The effect of metacognitive training on mathematical word - problem solving. Journal of Computer Assisted Learning, 19(1), 46-55. https://doi.org/10.1046/j.0266-4909.2003.00005.x

Thorpe, G. (2006). Multilevel analysis of PISA 2000 reading results for the United Kingdom using pupil scale variables. School Effectiveness and School Improvement, 17(1), 33-62. https://doi.org/10.1080/09243450500264473

USAID. (2008). Evaluation of the Jordan Education Initiative: Report: Task 1. In D. Light \& C. Rockman (Eds.), The Emerging Paradigm of Teaching and Learning in Discovery Schools. Jordan: Education Development Center, Inc.

Vermunt, J. D., \& Vermetten, Y. J. (2004). Patterns in student learning: Relationships between learning strategies, conceptions of learning, and learning orientations. Educational Psychology Review, 16(4), 359-384. https://doi.org/10.1007/s10648-004-0005-y

Wolters, C. A., Pintrich, P. R., \& Karabenick, S. A. (2005). Assessing academic self-regulated learning. Paper presented at the Indicators of Positive Development: Definitions, Measures, and Prospective Validity, Washington, DC. https://doi.org/10.1007/0-387-23823-9_16

Wood, D., Bruner, J. S., \& Ross, G. (1976). The role of tutoring in problem solving. Journal of Child Psychology and Psychiatry, 17(2), 89-100. https://doi.org/10.1111/j.1469-7610.1976.tb00381.x

Wu, M. (2005). The role of plausible values in large-scale surveys. Studies in Educational Evaluation, 31(2), 114-128. https://doi.org/10.1016/j.stueduc.2005.05.005

\section{Notes}

Note 1. Critical thinking used in this research refers "to the acquisition of deep and meaningful understanding as well as content-specific critical inquiry abilities, skills, and dispositions" (Garrison, Anderson, \& Archer, 2001, p. 2).

Note 2. Surface cognitive Strategies are strategies employed by learners when they tend to focus on main points and reproducing main facts. This happens when fewer efforts are paid on information remembering resulting into memorization.

Note 3. This project aims at delivering E-content like E-English and E-math using ICT in a selected number of schools in Amman, the capital of Jordan.

Note 4. Education is segregated by sex in the Arab contexts that make an excellent opportunity to examine gender differences in many areas including reading in first and second or foreign language.

\section{Copyrights}

Copyright for this article is retained by the author(s), with first publication rights granted to the journal.

This is an open-access article distributed under the terms and conditions of the Creative Commons Attribution license (http://creativecommons.org/licenses/by/4.0/). 